\title{
OCCUPATIONAL RISK MANAGEMENT AT PRODUCTION PLANTS IN POLAND DURING THE COVID-19 EPIDEMIC
}

\author{
Krzysztof NOWACKI, Sandra GRABOWSKA, \\ Karolina ŁAKOMY, Wioletta OCIECZEK \\ Silesian University of Technology
}

\begin{abstract}
:
The epidemic is affecting the global economy, plunging many industries. The global scale of the epidemic and government controls, restrictions and constraints have led to imbalances in world trade and have put many companies under pressure. The epidemic is a test of individual companies' ability to operate effectively under new conditions, including occupational risk management. The research was conducted using a questionnaire method, the study was attended by 199 respondents. The research is burdened with an error in the selection of statistical sample units, which resulted from the respondents' involvement and their truthfulness. The research was burdened with an estimation error of 0.07 . The research was divided into two parts related to freezing the economy and social life and their defrosting. The aim of the article is to assess the occupational risk management activities that determine the prevention of OSH in an extreme situation, which was the immediate freezing of the economy and social activity in connection with the epidemic and then their gradual unfreezing. The conducted research allowed confirming the accepted hypothesis that the effectiveness of actions protecting the health of employees, and thus the production capacity of enterprises in a crisis situation, is related to the size of the plant, and this may be indirectly related to the system of organization of occupational health and safety services in the country.
\end{abstract}

Key words: occupational risk management, COVID-19, production plants

\section{INTRODUCTION}

The epidemic started on 17 November 2019 in the city of Wuhan, Hubei Province in central China, and was declared a pandemic by the World Health Organisation (WHO) on 11 March 2020. Initially, the World Health Organization decided not to recognize the epidemic as a public health emergency of international scope. The WHO previously warned that further spread of the disease was possible. On 24 January 2020, the first case of infection in Europe was confirmed. The infection was diagnosed in two people: one in Paris and the other in Bordeaux. In the second half of February, larger outbreaks started to appear outside China. On 4 March 2020, the first case of coronavirus was reported in Poland.

The coronavirus epidemic changed the way many companies work every day. A significant part of companies started to work remotely, but not in all companies, e.g. production or health care, this mode of work is possible. Despite the progressing digitisation, robotisation and automation, there is no effectively functioning factory or enterprise without people.
The physical work of people is necessary to maintain the continuity of the plant $[1,2]$.

Due to the increasing number of COVID-19 cases in Poland and Europe, employers are forced to take special steps to minimize the spread of the virus, ensure continuity of work and business operations [3, 37].

Large companies, in accordance with Polish legislation, are obliged to separate health and safety cells from their structures and employ specialists. Small and medium enterprises do not have such an obligation, and OSH tasks may be performed by employers, employees employed in other works or specialists from outside the company. In addition, large establishments are usually delegations of multinational corporations that have corporate solutions in place. Based on the analysis of the literature, a research gap has been identified in the field of occupational risk management in unusual situations, such as an epidemic. The aim of the article is to assess the activities related to occupational risk management, which determines the activities related to the prevention of ersian extreme situation, which was the immediate freezing of the economy 
and social activity in connection with the epidemic and then their gradual unfreezing. Therefore, it was assumed that the effectiveness of measures to protect workers' health, and thus the production capacity of companies in a crisis situation, is related to the size of the plant. A function of the time and size of the production company was taken as the comparative criterion.

\section{REVIEW OF THE SUBJECT LITERATURE}

In Poland, occupational risk assessment is one of the employer's basic obligations in terms of occupational safety. The legal reference to occupational risk appeared for the first time in the EU legislation in the so-called Framework Directive, concerning safety and health protection at work [4]. The aim of the Directive was to unify and increase the level of safety by, inter alia, assessing risks, preventing risks and combating their sources. It is recognised that occupational risk assessment was the most important element of the EU guidelines, as evidenced by detailed provisions on hazard identification, participation of workers in the assessment, introduction of measures to eliminate risks at source, documentation and periodic evaluation of risks in workplaces. The legislation guaranteed Member States the introduction of minimum safety requirements, which led some countries to significantly increase safety levels [5] when transposing the legislation, while in other countries these levels were already significantly higher than proposed.

National law on occupational safety and risk is governed by a number of legal acts, including the General Health and Safety Regulations [6]. The definition of occupational risk is presented there, which should be understood as the probability of occurrence of undesirable events related to the performed work, causing losses, in particular the occurrence of adverse health effects in employees as a result of occupational hazards occurring in the work environment or the way of performing work. The national authority, in these regulations, indicates the obligations of employers with regard to the assessment of occupational risk, emphasizing that the assessment should take into account all factors of the working environment during the work.

The issues concerning the documentation of the occupational risk assessment, which should include a description of the evaluated workplace, together with the machines and materials used, the tasks performed, the nuisance, harmful and dangerous factors present at the workplace, the personal and collective protection equipment used, and a list of persons working at the workplace is also regulated. The documentation should then include the results of the occupational risk assessment for each identified hazard and a proposal for necessary preventive solutions to reduce the level of occupational risk. The documentation must include the date of the assessment and a list of persons carrying out the analysis. The legislator also imposes an obligation on employers to apply preventive measures, methods and organization of work, ensuring an increase in the level of safety and health protection for employees, which should be integrated into the activity and organizational structure of the enterprise [6].

The subject of assessing and documenting occupational risk is also addressed in the Labour Code Act, where the employer is obliged to assess and apply the necessary preventive measures to reduce risk. In addition, employees should be informed about the results of the assessment and the principles of protection against hazards [7, 38]. Conducting and documenting the risk assessment is mandatory, but the choice of the assessment method is free, depending on the preferences, possibilities or skills of the assessors, the specificity of the workplace or the availability of the method itself, e.g. on OSH platforms.

The COVID-19 epidemic has caused employers in Europe, including Poland, to struggle with the problem of ensuring safety at work, taking into account the biological risks that the COVID-19 virus has so far overlooked [8]. Although occupational risk assessments at production plants have included risks in the form of viruses such as influenza, despite the high seasonal probability of the threat, the effects were small and exposure was easy to reduce. A slightly different, more serious situation is the case for the currently spreading virus. The European Agency for Safety and Health at Work has published an EU guide on workplace adaptation during the COVID-19 epidemic. As risk assessment is the starting point in occupational safety management $[9,10]$, it is assumed that employers are required to verify the level of risk when there are any changes to the work process, even if they only affect workers' mental health. It is suggested that this additional risk assessment should also be based on current data on the prevalence of COVID-19 in the area where the company operates. Good risk assessment practices impose an obligation to eliminate risks from workstations, but in the case of the risk under consideration, only the exposure of workers can be minimised by implementing collective preventative solutions and then providing personal protective equipment [11]. The organisational solutions proposed to reduce the level of occupational risk are primarily

- limiting the work to what is necessary,

- the provision of remote services,

- avoiding outsiders,

- exclude physical contacts between employees and customers, and if this is not possible, it is recommended to limit contacts to 15 minutes preferably in the open air, keeping a distance.

Health prevention training and other forms of communication, such as instructions, are an important element in reducing risks. Technical solutions include providing soap, disinfectants, placing impermeable covers between workers, equipping workers with masks. When choosing prophylactic agents, it is important to remember that they do not cause new risks [12]. 
The COVID-19 virus epidemic in Poland has made it necessary to introduce and apply sanitary rigours $[13,14,15$, $16,17,18,19]$. These restrictions could be taken into account by employers as prophylactic solutions in updated risk assessments at workstations. The national legislator obliged employers to provide employees with disposable gloves or hand disinfectants. In addition, an obligation was introduced to maintain a distance between workstations of at least $1.5 \mathrm{~m}$, and in the absence of such a possibility there was a need to use personal protective equipment. Customer service stations should be regularly disinfected.

Further government guidelines introduced an obligation to cover the mouth and nose. By the date of completion of the surveys, despite the almost complete unfreezing of the economy, the state imposed restrictions on workplaces had not been lifted. The guidelines issued by the Ministry of Development [20] were also helpful in updating occupational risk assessments during epidemics in industrial plants. The government developed procedures to ensure greater safety for workers in industrial enterprises by implementing the following proposals:

- avoiding the infection of employees with the virus by strangers (suppliers, customers),

- reduce the number of physical contacts on the premises, create small work teams, implement contactless temperature measurement of employees and guests before entering the premises,

- ensuring protection of faces and hands of all workers, limiting the use of common spaces,

- changes in the hours of rest,

- to enable remote working.

Occupational risk management is, above all, the continuous cooperation with employees, who should be aware of the importance of their health and safety on a daily basis and during an epidemic, and this can only be achieved through interdependence with their subordinates, trust and joint problem solving [21, 22]. The new risk of COVID19 must be thought of wisely, minimising exposure, but also be aware that it is not possible to eliminate the risk completely within the companies.

\section{MATERIAL AND METHODS}

The research material consisted of the results of surveys carried out among the employees of H\&S services employed in manufacturing companies in Poland. Each of the respondents presented information about one plant where they are employed, so it was assumed that the number of surveyed enterprises is equal to the number of respondents. The research was conducted in six stages at two-weekly intervals, on days: 18-19 March 2020, 1-2 April 2020, 15-16 April 2020, 29-30 April 2020, 13-14 May 2020, 27-28 May 2020. The research was divided into two parts related to freezing the economy and social life (stages I to III) and their defrosting (stages IV to VI). Re- spondents answered the questionnaire questions presented in Table 1. Apart from the questionnaire, data on seniority in OSH service in years, company size (small or medium enterprise employing up to 249 employees, large enterprise employing over 249 employees) were collected. Due to the limitations of direct communication, the questionnaire was distributed on industry forums by means of social media and with the participation of the National Association of OSH Service Employees.

Simultaneously with the surveys, current monitoring of the legal status and sanitary guidelines for employers in Poland and epidemiological monitoring in Poland and worldwide was conducted.

Table 1

Research questionnaire

No Question Possible

answers

No Qunstion

In connection with COVID-19,

1 I am updating the plant risk assessment

YES NO

In connection with COVID-19,

2 I am updating the work instructions for the positions

YES NO

For COVID-19, I am equipping

3 staff with additional Personal Protective Equipment

YES NO

The information available on

4 COVID-19 is enough for me, I know what to do

Definitely No 12345 Definitely Yes

During an ongoing pandemic,

5 my plant makes employees feel safe

Definitely No 12345 Definitely Yes

Employees always follow 6* plant changes related to COVID-19

Definitely No 12345 Definitely Yes

* Testing in stages II-VI.

Table 2 presents the number of confirmed infections and deaths in Poland and worldwide, in connection with COVID-19 during the successive stages of the research. The results were analysed statistically, in the following ranges:

- normal distribution test - Lilliefors test [24],

- comparative analysis of ordered categories - ANOVA Kruskal-Wallis test [25] and POST-HOC test with Bonferroni's Dunn correction [26],

- comparative analysis of unordered categories Pearson's chi-quadrant (RxC) test [27],

- Jonckheere-Terpstra trend test [28, 29]. 
Table 2

Epidemic situation during the survey

\begin{tabular}{|c|c|c|c|c|c|c|c|c|c|c|}
\hline \multirow{3}{*}{ 峁 } & \multicolumn{4}{|c|}{$\begin{array}{l}\text { Number of confirmed infections } \\
\text { in relation to COVID-19 }\end{array}$} & \multicolumn{4}{|c|}{$\begin{array}{l}\text { Number of confirmed deaths } \\
\text { in connection with COVID-19 }\end{array}$} & \multirow{2}{*}{\multicolumn{2}{|c|}{$\begin{array}{l}\text { Number of countries } \\
\text { with COVID-19 confirmed }\end{array}$}} \\
\hline & \multicolumn{2}{|c|}{ Start of research } & \multicolumn{2}{|c|}{ End of research } & \multicolumn{2}{|c|}{ Start of research } & \multicolumn{2}{|c|}{ End of research } & & \\
\hline & Poland & $\begin{array}{l}\text { Word } \\
\text { [thou.] }\end{array}$ & Poland & $\begin{array}{l}\text { Word } \\
\text { [thou.] }\end{array}$ & Poland & $\begin{array}{l}\text { Word } \\
\text { [thou.] }\end{array}$ & Poland & $\begin{array}{l}\text { Word } \\
\text { [thou.] }\end{array}$ & $\begin{array}{c}\text { Start } \\
\text { of research }\end{array}$ & $\begin{array}{l}\text { End } \\
\text { of research }\end{array}$ \\
\hline 1 & 238 & 198.2 & 355 & 244.5 & 5 & 8.0 & 5 & 10.0 & 155 & 160 \\
\hline ॥ & 2311 & 859.8 & 2946 & 1016.5 & 33 & 42.3 & 57 & 56.2 & 180 & 181 \\
\hline III & 7202 & 1982.6 & 7918 & 2159.3 & 263 & 126.8 & 314 & 145.6 & 185 & 185 \\
\hline IV & 12218 & 3117.2 & 12877 & 32580.0 & 596 & 217.2 & 644 & 233.4 & 185 & 187 \\
\hline V & 16921 & 4262.8 & 17615 & 4444.0 & 839 & 292.0 & 883 & 302.5 & 187 & 188 \\
\hline $\mathrm{VI}$ & 22074 & 5593.1 & 22825 & 5813.9 & 1024 & 350.5 & 1038 & 360.4 & 188 & 188 \\
\hline
\end{tabular}

Source: own elaboration based [23].

For each of the tests carried out, the confidence level $\alpha<0.05$ was assumed. The results were coded depending on the requirements of the method. The method of coding was presented each time the test results were presented. Analyses were conducted using Microsoft Excel 2019 and PQStat v 1.6.8.384.

The number of questionnaires (of the assessed production companies) obtained in the analysed stages is presented in Table 3.

Table 3 Number of questionnaires (enterprises)

\begin{tabular}{|c|c|c|c|}
\hline \multirow{2}{*}{ Stage } & \multicolumn{2}{|c|}{ Enterprises } & \multirow{2}{*}{ Total } \\
\hline & Large & Small and medium & \\
\hline I & 74 & 51 & 125 \\
\hline II & 31 & 22 & 53 \\
\hline III & 32 & 15 & 47 \\
\hline IV & 26 & 28 & 54 \\
\hline v & 39 & 19 & 58 \\
\hline VI & 27 & 14 & 41 \\
\hline
\end{tabular}

\section{RESULTS AND DISCUSSION}

The results obtained for questions 1-3 concerning updating the risk assessment, safety instructions and equipping workers with additional personal protective equipment are presented in Table 4. The results of the tests were subjected to a chi-quadrant test $(\mathrm{RxC})$, obtaining the following results:

- question 1 - chi-quadrat 19.719, $p=0.001$;

- question 2 - chi-quadratic statistics 5.231, $p=0.388$;

- question 3 - chi-quadratic statistics 26.039, $p<0.001$. Based on statistics $p$, a statistically significant difference was found between the results of questions 1 and 3 concerning updating the risk assessment and equipping workers with additional personal protective equipment in individual stages of the study. No such differences in the middle values were found in question 2 .

The results of the research on updating the risk assessment, safety instructions and equipping workers with additional protective equipment, broken down by size of the company, are presented graphically in Fig. 1-3.
Table 4

Results of studies on updating the Occupational Risk Assessment, health and safety instructions and equipping workers with additional personal protective equipment in industrial plants during the pandemic

\begin{tabular}{|c|c|c|c|c|c|c|}
\hline \multirow[t]{2}{*}{ 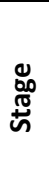 } & \multicolumn{2}{|c|}{$\begin{array}{c}\text { Question } 1 \\
\text { (Occupational Risk } \\
\text { Assessment) }\end{array}$} & \multicolumn{2}{|c|}{$\begin{array}{l}\text { Question } 2 \\
\text { (Safety } \\
\text { instructions) }\end{array}$} & \multicolumn{2}{|c|}{$\begin{array}{l}\text { Question } 3 \\
\text { (Individual } \\
\text { protection } \\
\text { measures) }\end{array}$} \\
\hline & Yes [\%] & No [\%] & Yes [\%] & No [\%] & Yes [\%] & No [\%] \\
\hline 1 & 29.6 & 70.4 & 32.8 & 67.2 & 78.4 & 21.6 \\
\hline II & 26.4 & 73.6 & 24.5 & 75.5 & 94.3 & 5.7 \\
\hline III & 34.0 & 66.0 & 34.0 & 66.0 & 95.7 & 4.3 \\
\hline IV & 31.5 & 68.5 & 40.7 & 59.3 & 94.4 & 5.6 \\
\hline V & 48.3 & 51.7 & 37.9 & 62.1 & 94.8 & 5.2 \\
\hline VI & 61.0 & 39.0 & 27.4 & 75.6 & 97.6 & 2.4 \\
\hline
\end{tabular}

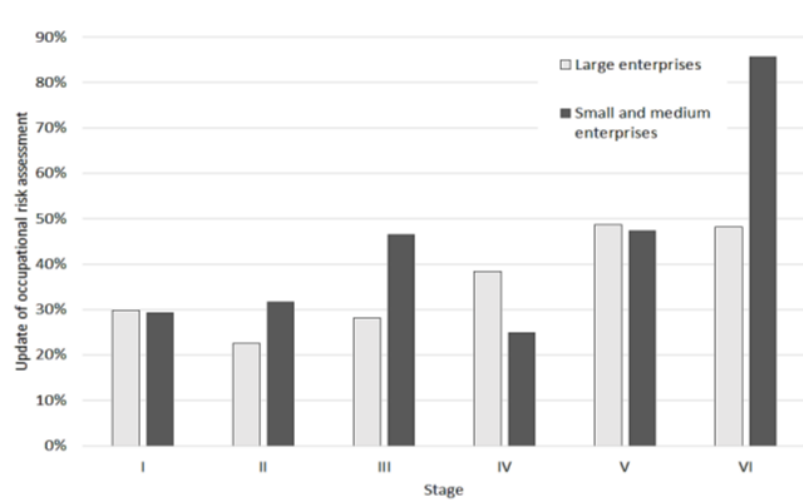

Fig. 1 Update on occupational risk assessment in enterprises during a pandemic (large enterprise $p=0.105$; small and medium enterprises $p=0.002$ )

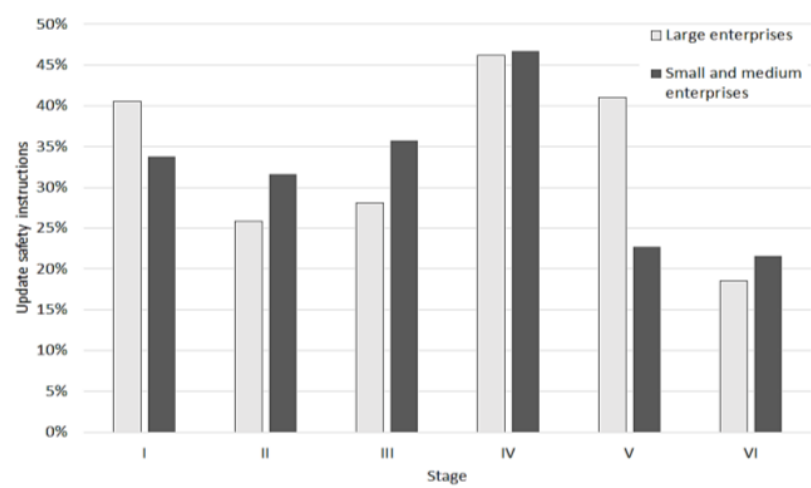

Fig. 2 Update on safety instructions in enterprises during a pandemic (large enterprise $p=0.151$; small and medium enterprises $p=0.420$ ) 


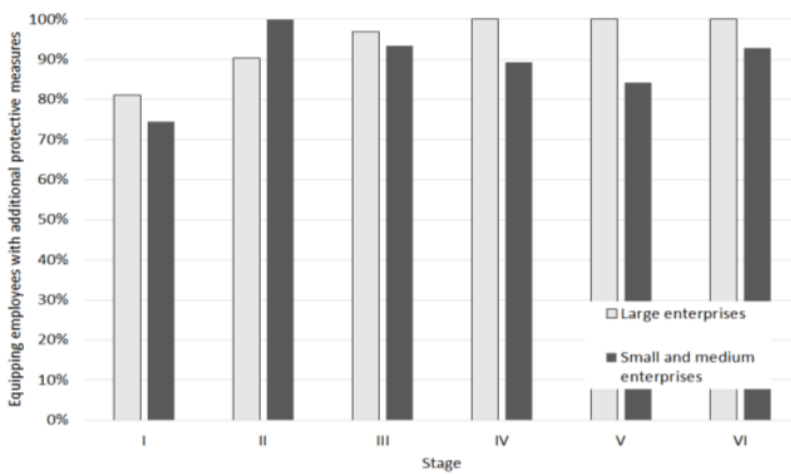

Fig. 3 Equipping employees with additional protective measures during a pandemic (large enterprise $p<0.001$; small and medium enterprises $p=0.059$ )

The results of the research presented above concern systemic activities related to the implementation of legal obligations by enterprises. These actions in a crisis situation, which was a coronavirus epidemic, make it possible to assess the effectiveness of adopted procedures and readiness to implement them by industrial enterprises. In the case of risk assessment, about $30 \%$ of production plants carried out its update, and this state of affairs persisted until stages 5 and 6 , in which an increase in such activities was observed to $48 \%$ in stage V and $60 \%$ in stage VI. Statistical significance of differences between the results was found $(p=0.001)$. In the case of SMEs, large fluctuations of results were found in particular stages of research (Fig. 1). Assuming that representatives of various enterprises participated in particular stages of the research, it may be assumed that in the SME sector there was a large discrepancy in actions undertaken. It should be noted that occupational risk assessment should be the basis for further actions, however, on the basis of the presented results, it can be concluded that many establishments have submitted ad hoc practical actions over systemic ones.

The document that should accompany the employee on a daily basis is the instruction for safe work. Such a document should instruct on all necessary protective measures, both organisational and technical, including those related to epidemics. For example, when using protective gloves, it should instruct how to take them off properly and how to proceed with the used protective equipment. On the basis of the research carried out, it was found that safety instructions at the beginning of the epidemic were updated in about $30-40 \%$ of industrial plants. During the epidemic, both during the period of freezing the production and its defrosting, and often when the enterprise was restarted after a shutdown, this percentage did not increase. No significant differences in this respect were also found in large or SME sectors (Fig. 2).

The operation of many plants could continue under strict sanitary regime, as indicated by the government services at the beginning of the pandemic. The results obtained indicate that at the beginning of the epidemic about $80 \%$ of the enterprises equipped their employees with additional SOPs, but in the next and following stages it was already about $80 \%$. $95 \%$ of employers. An increase in activity in this respect was observed both among SMEs and large enterprises, however, in the case of large enterprises, since the 4 th stage of the survey, i.e. since the time of gradual de-freezing of the economy, in this type of enterprises, employees have always been equipped with additional SOPs (Fig. 3). Most often they were gloves and masks or protective visors.

Questions 4-6 concerned the assessment of the situation inside the establishments by the health and safety workers. The respondents answered on the Likert scale in the range from 1 to 5 , where 1 meant the lowest mark and 5 the highest. The results of studies conducted using the Likert scale, determining descriptive statistics for each case, are presented in Table 5.

Table 5

Descriptive statistics of test results - questions 4-7

\begin{tabular}{|c|c|c|c|c|c|}
\hline 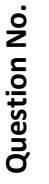 & 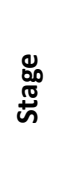 & 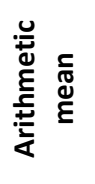 & 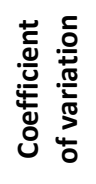 & 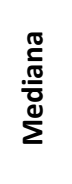 & 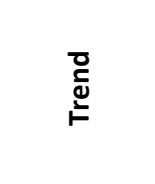 \\
\hline \multirow{6}{*}{4} & 1 & 3.784 & 0.280 & 4 & 5 \\
\hline & II & 4.264 & 0.185 & 4 & 5 \\
\hline & III & 4.106 & 0.211 & 4 & 5 \\
\hline & IV & 4.167 & 0.212 & 4 & Repeatedly \\
\hline & $\mathrm{V}$ & 4.397 & 0.153 & 4.5 & 5 \\
\hline & $\mathrm{VI}$ & 4.439 & 0.152 & 5 & 5 \\
\hline \multirow{6}{*}{5} & 1 & 3.248 & 0.314 & 3 & 3 \\
\hline & II & 3.434 & 0.283 & 3 & 3 \\
\hline & III & 3.809 & 0.249 & 4 & 4 \\
\hline & IV & 3.833 & 0.252 & 4 & 4 \\
\hline & $\mathrm{V}$ & 3.741 & 0.227 & 4 & 4 \\
\hline & $\mathrm{VI}$ & 3.805 & 0.188 & 4 & 4 \\
\hline \multirow{5}{*}{6} & II & 4.132 & 0.207 & 4 & 5 \\
\hline & III & 4.340 & 0.188 & 4 & 5 \\
\hline & IV & 4.093 & 0.248 & 4 & 5 \\
\hline & $\mathrm{V}$ & 3.466 & 0.266 & 3 & 3 \\
\hline & $\mathrm{VI}$ & 3.585 & 0.241 & 4 & 4 \\
\hline
\end{tabular}

Moreover, the distribution of results using the Lilliefors test was determined. For each of the analysed questions, the distribution was found to be different from normal $(p<\alpha)$. The differences in middle values were compared with the Kruskal-Wallis test and then POST-HOC test. The results are presented in Table 6.

The results of questions 4- 6 were coded, taking 3 as neutral, 1 and 2 as negative, 4 and 5 as positive. The obtained answers were juxtaposed by determining the percentages for each of the study stages. In order to determine the significance of differences between the results, they were subjected to the chi-quadrant test $(\mathrm{RxC})$. The obtained results are presented in Table 7. 
Table 6

Results of the Kruskal-Wallis test - questions 4-6 (own elaboration)

\begin{tabular}{|c|c|c|c|c|c|c|c|c|c|}
\hline \multirow[t]{2}{*}{ Question No. } & \multirow[t]{2}{*}{ Statistic H } & \multirow[t]{2}{*}{ Value $p$} & \multicolumn{7}{|c|}{ Test POST-HOC } \\
\hline & & & Stage & I & II & III & IV & V & $\mathrm{VI}$ \\
\hline & & & I & & 0.076 & 1 & 0.318 & 0.002 & 0.004 \\
\hline & & & II & 0.076 & & 1 & 1 & 1 & 1 \\
\hline \multirow[t]{7}{*}{4} & \multirow[t]{7}{*}{23.434} & \multirow[t]{7}{*}{$<0.001$} & III & 1 & 1 & & 1 & 1 & 1 \\
\hline & & & IV & 0.318 & 1 & 1 & & 1 & 1 \\
\hline & & & V & 0.002 & 1 & 1 & 1 & & 1 \\
\hline & & & VI & 0.004 & 1 & 1 & 1 & 1 & \\
\hline & & & Stage & I & ॥ & III & IV & V & $\mathrm{VI}$ \\
\hline & & & I & & 1 & 0.010 & 0.003 & 0.033 & 0.038 \\
\hline & & & $\|$ & 1 & & 0.443 & 0.256 & 1 & 0.824 \\
\hline \multirow[t]{6}{*}{5} & \multirow[t]{4}{*}{25.654} & \multirow[t]{4}{*}{$<0.001$} & III & 0.010 & 0.443 & & 1 & 1 & 1 \\
\hline & & & IV & 0.003 & 0.256 & 1 & & 1 & 1 \\
\hline & & & v & 0.033 & 1 & 1 & 1 & & 1 \\
\hline & & & VI & 0.038 & 0.824 & 1 & 1 & 1 & \\
\hline & \multirow{6}{*}{37.165} & \multirow{6}{*}{$<0.001$} & Stage & II & III & IV & & v & VI \\
\hline & & & $\|$ & & 1 & 1 & & 0.001 & 0.034 \\
\hline \multirow{4}{*}{6} & & & III & 1 & & 1 & & $<0.001$ & $<0.001$ \\
\hline & & & IV & 1 & 1 & & & $<0.001$ & 0.025 \\
\hline & & & v & 0.001 & $<0.001$ & $<0.001$ & & & 1 \\
\hline & & & VI & 0.034 & $<0.001$ & 0.025 & & 1 & \\
\hline
\end{tabular}

Table 7

Test results (answers to questions 4-6)

\begin{tabular}{|c|c|c|c|c|c|c|}
\hline Question No. & $\begin{array}{l}\text { Chi-quadrate } \\
\text { statistics }\end{array}$ & Value $p$ & Stage & $\begin{array}{c}\text { Evaluation [\% } \\
\text { Positive }\end{array}$ & Neutral & Negative \\
\hline \multirow{6}{*}{4} & \multirow{6}{*}{35.941} & \multirow{6}{*}{$<0.001$} & 1 & 60.0 & 30.4 & 9.6 \\
\hline & & & II & 79.3 & 27.7 & 0.0 \\
\hline & & & III & 72.4 & 25.5 & 2.1 \\
\hline & & & IV & 81.5 & 14.8 & 3.7 \\
\hline & & & V & 89.7 & 10.3 & 0.0 \\
\hline & & & VI & 90.2 & 9.8 & 0.0 \\
\hline \multirow{6}{*}{5} & \multirow{6}{*}{26.087} & \multirow{6}{*}{0.004} & 1 & 41.6 & 40.8 & 17.6 \\
\hline & & & II & 45.3 & 39.6 & 15.1 \\
\hline & & & III & 68.1 & 23.4 & 8.5 \\
\hline & & & IV & 66.7 & 27.8 & 5.6 \\
\hline & & & V & 65.6 & 25.9 & 8.6 \\
\hline & & & VI & 68.3 & 29.3 & 2.4 \\
\hline \multirow{5}{*}{6} & \multirow{5}{*}{32.305} & \multirow{5}{*}{$<0.001$} & II & 77.3 & 18.9 & 3.8 \\
\hline & & & III & 89.4 & 8.5 & 2.1 \\
\hline & & & IV & 79.6 & 13.0 & 7.4 \\
\hline & & & v & 46.6 & 41.4 & 12.0 \\
\hline & & & VI & 56.1 & 36.6 & 7.3 \\
\hline
\end{tabular}


Taking the size of the company as a comparative criterion, the obtained results are graphically presented in Fig. 4-6.

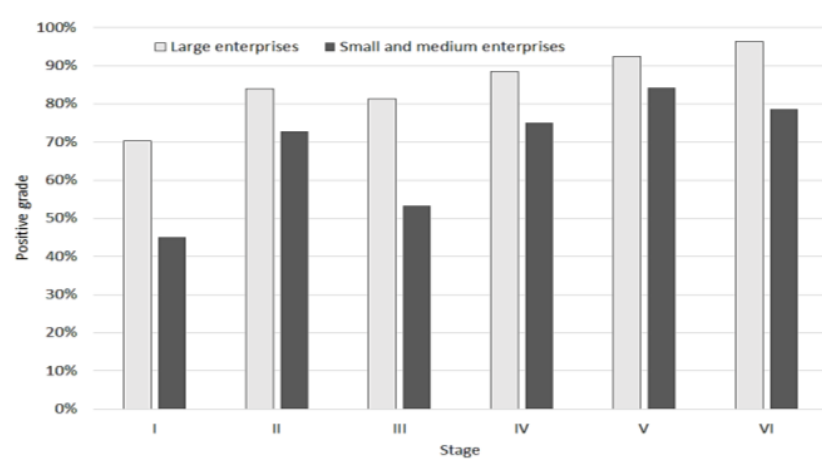

Fig. 4 Assessment of the availability of information on COVID19 (large enterprise $p=0.076$; small and medium enterprises $p=0.016)$

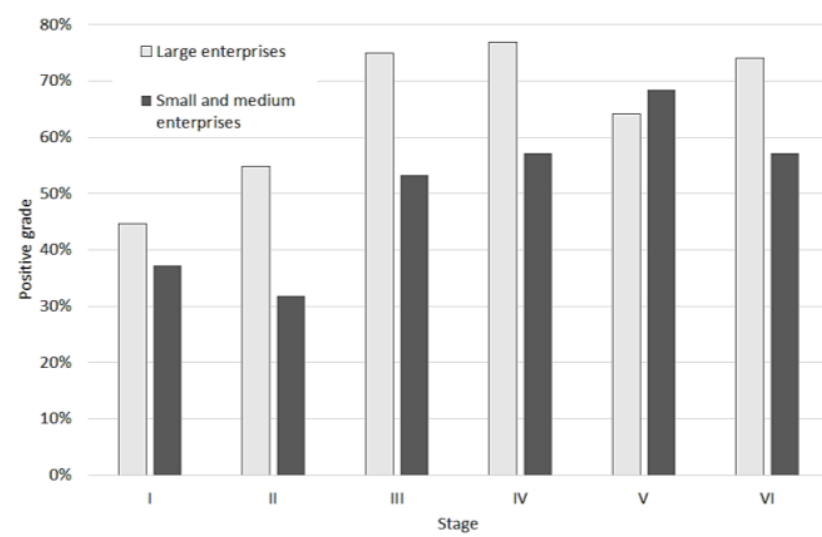

Fig. 5 Assessment of employees' sense of security at the plant during an ongoing pandemic (large enterprise $p=0.040$; small and medium enterprises $p=0.280$ )

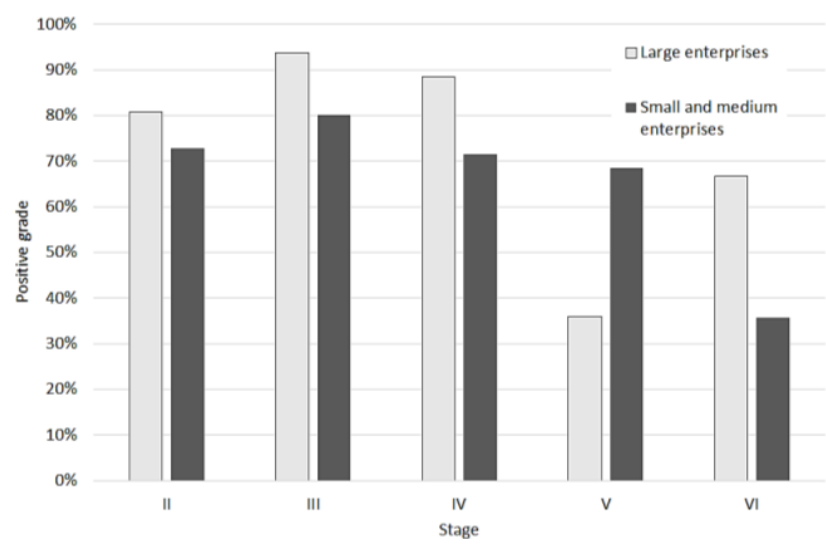

Fig. 6 Assessment of employees' compliance with changes introduced in the plant in connection with the ongoing pandemic (large enterprise $p<0.001$; small and medium enterprises $p=0.083$ )

All activities are based on knowledge. That is why access to information both inside and outside the company is so important in an emergency situation. Currently, apart from work-related stress, an employee is exposed to stress resulting from an epidemiological threat [30]. The employer's responsibility in a pandemic situation requires ensuring safe and hygienic working conditions and developing an appropriate way of communication and changing procedures [31]. Appropriate organisation of work, as well as proper communication about the risks associated with the emergency becomes important in this respect. Strengthening risk communication and organisation tailored to the situation and the workplace is particularly important when workers return to the companies. Correct (intensive) communication in the workplace should be continuous during a pandemic. Adequate information affects workers' sense of security, especially their mental well-being, and promotes discipline for the correct attitudes and behaviour of workers resulting from the relaxation of restrictions and a decline in self-discipline. Proper communication also affects the employee's level of trust in the employer, an employee who feels that the employer, the boss takes care of his or her health and life, will be motivated to get more involved in work. The experience of a pandemic situation for many employees can even be comparable to post-traumatic stress syndrome, due to the traumatic experience of fear for our own and our loved ones' lives and health and economic safety [32, 33]. In addition to providing the right specialist in the workplace, employers should also communicate with employees on how to find help outside the workplace [34, 35]. The availability of information at the beginning of the epidemic was particularly poorly assessed by health and safety professionals. In the first stage of the survey only $60 \%$ of workers rated access to information positively and about $10 \%$ negatively. However, in the case of large enterprises, i.e. with a systematic way of acting, usually in a systemic form, positive opinions were about $70 \%$ and in the SME sector only $45 \%$. Negative evaluations were similarly nearly 7 and $14 \%$ (Fig. 4). These results confirm the adopted hypothesis, indicating the necessity of systemic changes in the organization of the OHS service in the SME sector, not due to the lack of competence of this service, yet it is left in a crisis situation in many cases without necessary assistance. In subsequent stages of the research, the access to information related to the necessary requirements increased, reaching in the last two stages about $90 \%$ of positive assessments. Statistical differences were found in the assessments of stages I-IV and V-VI The average values of the test results in individual stages are presented in Fig. 7. The analysis conducted with the Jonckheere-Terpstra trend test confirmed the above observations (unilateral value $p<0.001$ ).

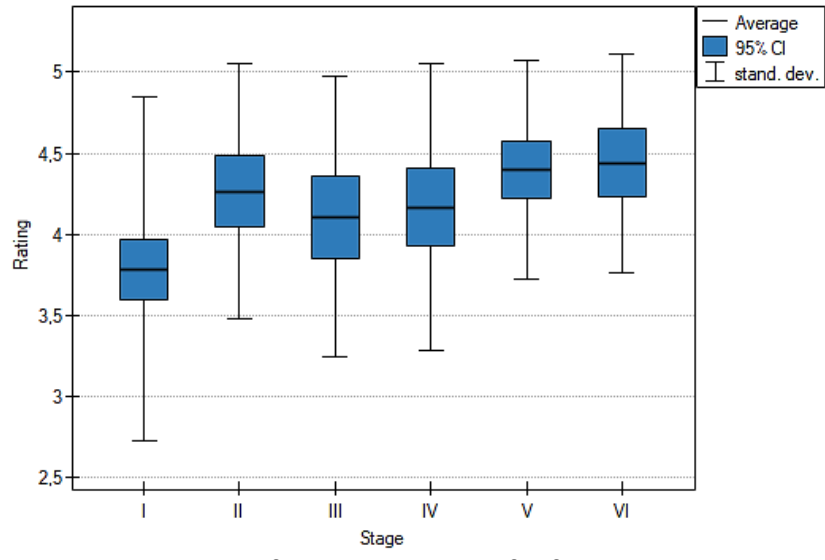

Fig. 7 Assessment of the availability of information on COVID19 in Poland 
According to the hierarchy of Maslow's needs, the need for safety is one of the basic human needs, right after the physiological need [36]. One of the forms of strengthening the sense of safety in the workplace is psychological support to help workers fight not only the objective and real threats of a pandemic, but also, and perhaps above all, the subjective ones, as fear in humans often has such causes and lies in the original survival instinct. Fear, on the one hand, acts as a warning signal and in this case it has a positive effect on the employee, but its disintegration and effectiveness-reducing effect is also known. In order to be able to perform their duties effectively and safely, workers must have a sense of proper work organisation which ensures their safety, even during an epidemic. On the basis of the conducted research it was found that the feeling of employees' safety increased as a function of time, from about $40 \%$ of positive assessments in stage I to about $70 \%$ in stage III, for which statistical differences of results were found by means of POST-HOC test. In this case an upward trend was also observed (unilateral value $p<0.001$ ). Graphically, the results of average values are presented in Fig. 8. The obtained results indicate the correctness of actions undertaken by manufacturing companies in the field of protection of workers during the epidemic, however, assuming the size of a plant as a comparative criterion, the feeling of safety at each stage was better by about $10 \%$ in large plants than in the SME sector (Fig. 5).

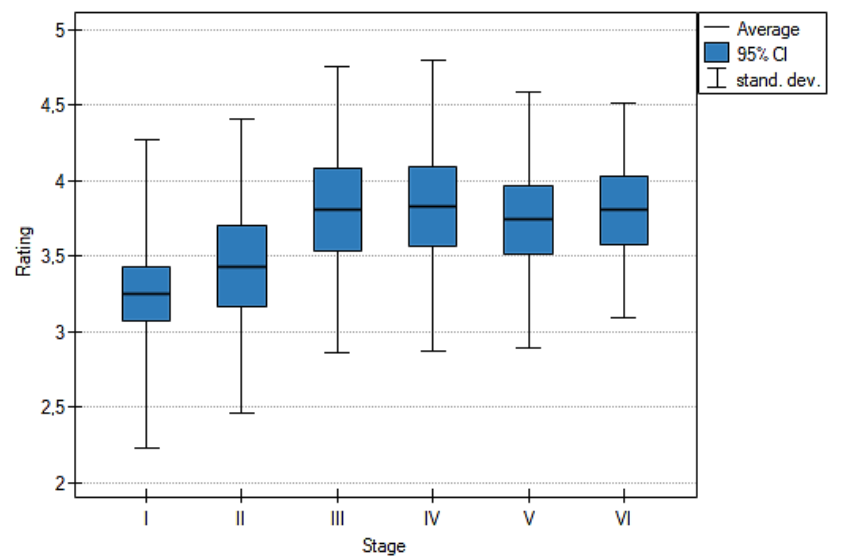

Fig. 8 Assessment of employees' sense of security during an ongoing pandemic in Poland

A sense of security is an implicit factor in the quality of the work performed, but may involve a reduction in self-discipline among employees and thus an unjustified risk of infection. The likelihood of reduced self-discipline may be due to the lack of a top-down example of enforcement of imposed regimes. The results of the conducted research indicate that up to stage IV, i.e. the beginning of unfreezing of the economy and social life, the positive assessment of employees' adaptation to the guidelines introduced in the establishments was about $80-90 \%$. In stages $\mathrm{V}$ and $\mathrm{VI}$ a drastic decrease in self-discipline among employees was found (45-55\% of positive assessments) presented in Figure 9. This trend, also noticeable in everyday life, was confirmed by the results of the POST-HOC test and the designated downward trend (unilateral value $p<0.001$ ).

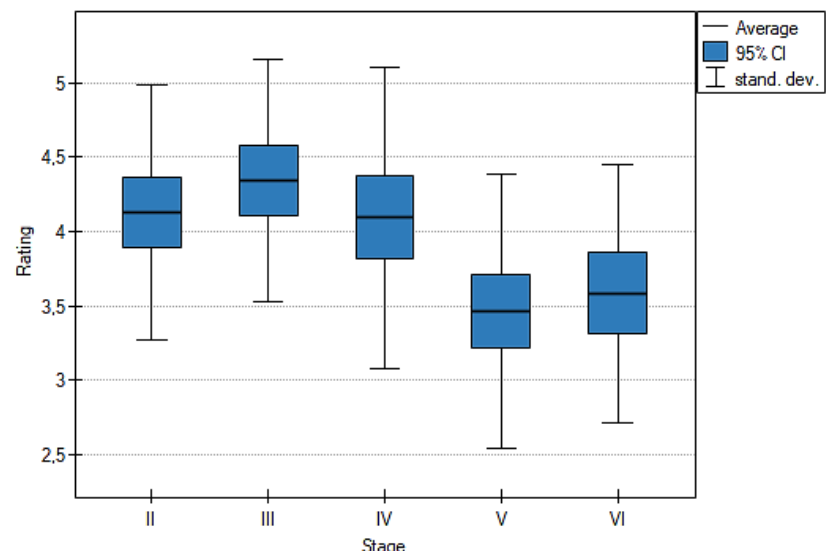

Fig. 9 Assessment of employees' adaptation to changes introduced in the plant in connection with the ongoing pandemic in Poland

The situation of change in most people evokes negative emotions. A change in employees is most often associated with resistance. Employees used to predictable situations in the face of change experience discomfort and even stress. The key element of adaptation to the process of change is correct information transfer, appropriate internal communication eliminating the situation of uncertainty among employees.

\section{CONCLUSION}

The health and safety service, as the employer's advisory service, must have clear, unambiguous, legible information on the epidemic situation and the necessary recommended measures to protect workers' health. That is why occupational risk management is so important for the smooth operation of companies in an epidemic situation of Covid-19, the analysis of which should be the basis for further, methodical actions aimed at protecting workers' health and life. The epidemic is a particularly difficult period for employers. It is a time when the role of OSH workers, as an employer's advisory service, is one of the key roles in preserving workers' health and this directly translates into the plant's production capacity.

The research carried out allowed to confirm the accepted hypothesis that the effectiveness of actions protecting workers' health, and thus the production capacity of enterprises in a crisis situation, is related to the size of the plant, and this can be indirectly connected with the system of organisation of health and safety services in the country. Currently, the vast majority of large enterprises have occupational safety management systems in place. Unfortunately, in the SME sector the percentage of these plants is much smaller. Moreover, according to national requirements, in Poland the OSH service in the sector of large enterprises is better organised than in the SME sector. The above affects the quality and speed of action in the field of protection of employees in a crisis situation. On the basis of the research carried out, it was found that during the pandemic, employers focused first of all on equipping workers with additional protective measures and secondly on methodical risk analysis resulting from the update of the occupational risk assessment. Employ- 
ees definitely followed sanitary regimes until the economy and social life were frostbite, which manifested itself, inter alia, in abolishing the absolute order to wear masks in public space and opening up public space to citizens. At that time, according to the health and safety service, the self-discipline of employees was loosened in relation to the sanitary obligations imposed on them in workplaces.

\section{ACKNOWLEGEMENT}

Silesian University of Technology (Faculty of Materials Engineering, Department of Production Engineering) supported this work as a part of Statutory Research $B K$ 229/RM1/2021 (11/010/BK_21/0032).

\section{REFERENCES}

[1] A. Moskvichev, N. Simonova, S. Vikhrov, V. Ivanov. "The system of labour protection based on the concept of occupational risk management." Occupational Safety and Safety in Construction no. 5, pp. 56-60, 2016.

[2] R. Santos, U. de Oliveira. "Analysis of occupational risk management tools for the film and television industry". International Journal of Industrial Ergonomics 72, pp. 199211, 2019.

[3] W. Cockburn. „Poradnik UE, COVID-19: Return to employment, Adapting the workplace and protecting workers", European Agency for Safety and Health at Work (EUOSHA), 2020.

[4] „Council Directive of 12 June 1989 on the introduction of measures to encourage improvements in the safety and health of workers at work" 89/391/EWG (Dyrektywa Rady z dnia 12 czerwca 1989 r. w sprawie wprowadzenia środków w celu poprawy bezpieczeństwa i zdrowia pracowników w miejscu pracy 89/391/EWG)

[5] „Communication from the Commission to the European Parliament, the Council", the European Economic and Social Committee and the Committee of Regions on the practical implementation of the provisions of the Health and Safety at Work Directives 89/391 (Framework), 89/654 (Workplaces), 89/655 (Work Equipment), 89/656 (Personal Protective Equipment), 90/269 (Manual Handling of Loads) and 90/270 (Display Screen Equipment), Brussels, 05.02.2004 COM(2004) 62 final.

[6] „The Health and Safety Service Regulation”. Internet: http://isap.sejm.gov.pl/isap.nsf/DocDetails.xsp?id=WDU1 9971290844 [Jun. 17, 2020].

[7] „Act of 26 June 1974 - Labour Code” (Dz.U.2019.0.1040)

[8] A. Mansour. „Evaluation of health and safety management systems in the Sudanese industrial corporations: An external audit perspective. Khartoum Univ". J. Manage. Stud., Vol. 11 no. 1, pp. 5-14, 2018.

[9] D. Chiroli, A. Baú, F. Deschamps, E. Sakakibara, L. Christóforo. „Work safety management applied to a lab used by a junior company of chemical engineering." Independent Journal of Management \& Production, 2019. DOI:10.14807/ijmp.v10i1.787

[10] B. Kaassis, A. Badri. „Development of a preliminary model for evaluating occupational health and safety risk management maturity in small and medium-sized enterprises." Safety, Vol. 4 no. 1 , art. no. 5., 2018. DOI:10.3390/safety 4010005

[11] R. McKinnon. Designing an Occupational Health and Safety Management System (SMS). The Design, Implementation, and Audit of Occupational Health and Safety Management Systems. Taylor Francis, London 2019.
[12] „WHO's guide Getting your workplace ready for COVID19". Internet: https://www.who.int/docs/defaultsource/coronaviruse/getting-workplace-ready-for-covid19.pdf [Jun. 17, 2020].

[13] „Ordinance of the Council of Ministers of 10 April 2020 on establishing certain restrictions, orders and prohibitions in connection with the occurrence of an epidemic state" (Dz. U. 2020 poz. 658)

[14] „Ordinance of the Council of Ministers of 15 April 2020 amending the Ordinance on the establishment of certain restrictions, orders and prohibitions in connection with the occurrence of an epidemic state" (Dz. U. 2020 poz. 673)

[15] „Ordinance of the Council of Ministers of 2 September 1997 on the occupational health and safety service" (Dz. U. 1997,109,704 ze zm.)

[16] „Ordinance of the Council of Ministers of 31 March 2020 on establishing certain restrictions, orders and prohibitions in connection with the occurrence of an epidemic state" (Dz. U. 2020 poz. 566)

[17] „Ordinance of the Minister of Health of 13 March 2020 on the declaration of an epidemic hazard state in the Republic of Poland" (Dz. U. 2020 poz. 433)

[18] „Ordinance of the Minister of Health of 20 March 2020 on declaring the state of the epidemic on the territory of the Republic of Poland" (Dz. U. 2020 poz. 491)

[19] „Ordinance of the Minister of Health of 24 March 2020 amending the Ordinance on declaring the state of the epidemic in the Republic of Poland" (Dz. U. 2020 poz. 522)

[20] „Koronawirus: infomracje i zalecenia." Internet: https://www.gov.pl/web/koronawirus/aktualne-zasady-iograniczenia [Jun. 17, 2020].

[21] E. Sugak. "The nature of occupational injuries in the aspect of managing pro-fess-regional risks." Life Safety, no. 7, pp. 3-7, 2015.

[22] E. Sugak. "Occupational Risks Management as a Basis of Industrial Injuries and Occupational Disease Prevention," IOP Conference Series: Materials Science and Engineering, vol. 365, 062038, 2018.

[23] www.esri.pl [Jun. 17, 2020].

[24] H. Lilliefors. „On the Kolmogorov-Smimov test for normality with mean and variance unknown." Journal of the American Statistical Association, Vol. 62, pp. 399-402, 1967.

[25] W. Kruskal. „A nonparametric test for the several sample problem." Annals of Mathematical Statistics, vol. 23, pp. 525-540, 1952.

[26] O. Dunn. „Multiple comparisons using rank sums.” Technometrics, Vol. 6, pp. 241-252, 1964.

[27] R. Plackett. „Karl Pearson and the Chi-Squared Test.” International Statistical Review. Vol. 51, no. 1, Apr. 1983. DOI:10.2307/1402731

[28] A. Jonckheere. „A distribution-free k-sample test against ordered alternatives." Biometrika, Vol. 41, pp. 133-145, 1954.

[29] T. Terpstra. „The asymptotic normality and consistency of Kendall's test against trend, when ties are present in one ranking." Indagationes Mathematicae, Vol. 14, pp. 327333, 1952.

[30] A. Shuttleworth. „Managing workplace stress: how training can help." Ind Commer Train. Vol. 36, No. 2, pp. 61-5, 1964.

[31] A. Rudnicka. „Egzamin ze społecznej odpowiedzialności w czasach koronawirusa." Intenret: https://mlodziwlodzi.pl/egzamin-ze-spolecznej-odpowiedzialnosci-w-czasach-koronawirusa/ [Jun. 17, 2020]. 
[32] C. Cooper, P. Dewe, M. O'Driscoll. Organizational Stress: A Review and Critique of Theory, Research, and Applications. London, United Kingdom: Sage, 2001.

[33] A. Bakker, W. Schaufeli W. „Positive organizational behavior: Engaged employees in flourishing organizations." Journal of Organizational Behavior, Vol. 29, pp. 147-154, 2001.

[34] F. Graetz, A. Smith. "Managing Organizational Change: A Philosophies of Change Approach." Journal of Change Management, Vol. 10, pp. 135-154, 2010.

[35] P. Klarner, R. By, T. Diefenbach. „Employee Emotions during Organizational Change - towards a New Research Agenda." Scandinavian Journal of Management, vol. 27, pp. 332-340, 2011.

\section{Krzysztof Nowacki}

ORCID ID: 0000-0003-2925-084X

Silesian University of Technology

Faculty of Materials Engineering

Department of Production Engineering

ul. Krasińskiego 8, 40-019 Katowice, Poland

e-mail: krzysztof.nowacki@polsl.pl

\section{Sandra Grabowska}

ORCID ID: 0000-0002-0478-3466

Silesian University of Technology

Faculty of Materials Engineering

Department of Production Engineering

ul. Krasińskiego 8, 40-019 Katowice, Poland

e-mail: sandra.grabowska@polsl.pl

\section{Karolina Łakomy}

ORCID ID: 0000-0001-7491-1542

Silesian University of Technology

Faculty of Materials Engineering

Department of Production Engineering

ul. Krasińskiego 8, 40-019 Katowice, Poland e-mail: karolina.lakomy@polsı.pl

\section{Wioletta Ocieczek}

ORCID ID: 0000-0003-2512-5494

Silesian University of Technology Faculty of Materials Engineering Department of Production Engineering ul. Krasińskiego 8, 40-019 Katowice, Poland e-mail: wioletta.ocieczek@polsl.pl
[36] S. Patric, H. Cormier. „Are Our Lives the Experiment? COVID-19 Lessons during a Chaotic Natural Experiment A Commentary." Health Behavior And Policy Review, Vol. 7, No. 2, pp.165-169, 2020. DOI: 10.14485/HBPR.7.2.10

[37] N. Baryshnikova, O. Kiriliuk, D. Klimecka-Tatar. „Enterprises' strategies transformation in the real sector of the economy in the context of the COVID-19 pandemic". Production Engineering Archives, vol. 27, No.2. pp. 8-12, 2021. DOI:10.30657/pea.2021.27.02

[38] A. Woźny. „Selected problems of managing work safety case study", Production Engineering Archives 2020, vol. 26. No. 3, pp. 99-103, DOI:10.30657/pea.2020.26.20 